\title{
Increased dietary protein for lactating sows affects body composition, blood metabolites and milk production
}

\author{
A. V. Strathe ${ }^{1 \dagger}$, T. S. Bruun², A.-H. Tauson ${ }^{1}$, P. K. Theil ${ }^{3}$ and C. F. Hansen ${ }^{1}$ \\ ${ }^{1}$ Department of Veterinary and Animal Sciences, Faculty of Health and Medical Sciences, University of Copenhagen, Grønnegårdsvej 2, 1870 Frederiksberg, Denmark; \\ ${ }^{2}$ SEGES Pig Research Centre, Axeltorv 3, 1609 Copenhagen, Denmark; ${ }^{3}$ Department of Animal Science, Blichers Allé 20, Aarhus University, 8830 Tjele, Denmark
}

(Received 12 February 2017; Accepted 2 July 2019; First published online 1 August 2019)

\begin{abstract}
Hyper-prolific sows nurse more piglets than less productive sows, putting a high demand on the nutrient supply for milk production. In addition, the high production level can increase mobilization from body tissues. The effect of increased dietary protein $(104,113,121,129,139$ and $150 \mathrm{~g}$ standardized ileal digestible (SID) CP/kg) on sow body composition, milk production and plasma metabolite concentrations was investigated from litter standardization (day 2) until weaning (day 24). Sow body composition was determined using the deuterium oxide dilution technique on days 3 and 24 postpartum. Blood samples were collected weekly, and milk samples were obtained on days 3, 10 and 17 of lactation. Litter average daily gain (ADG) peaked at $135 \mathrm{~g}$ SID CP/kg $(\mathbb{P}<0.001)$. Sow BW and back fat loss reached a breakpoint at 143 and $127 \mathrm{~g}$ SID CP/kg $(\mathbb{P}<0.001)$. Milk fat increased linearly with increasing dietary SID CP $(P<0.05)$, and milk lactose decreased until a breakpoint at $124 \mathrm{~g}$ SID CP/kg and $5.3 \%(\mathrm{P}<0.001)$ on day 17. The concentration of milk protein on day 17 increased until a breakpoint at $136 \mathrm{~g}$ SID CP/kg $(5.0 \% ; \mathrm{P}<0.001)$. The loss of body protein from day 3 until weaning decreased with increased dietary SID CP until it reached a breakpoint at $128 \mathrm{~g} S I D C P / \mathrm{kg}(\mathrm{P}<0.001)$. The body ash loss declined linearly with increasing dietary $S I D C P(P<0.01)$, and the change in body fat was unaffected by dietary treatment $(\mathrm{P}=0.41)$. In early lactation (day $3+$ day 10$)$, plasma urea $N$ (PUN) increased linearly after the breakpoint at $139 \mathrm{~g} S I D C P / \mathrm{kg}$ at a concentration of $3.8 \mathrm{mmol} / \mathrm{l}$, and in late lactation (day $17+$ day 24), PUN increased linearly after a breakpoint at $133 \mathrm{~g} S I D C P / \mathrm{kg}(\mathrm{P}<0.001)$ at a concentration of $4.5 \mathrm{mmol} / \mathrm{l}$. In conclusion, the $S I D C P$ requirement for sows was estimated to $135 \mathrm{~g} / \mathrm{kg}$ based on litter $A D G$, and this was supported by the breakpoints of other response variables within the interval 124 to $143 \mathrm{~g} / \mathrm{kg}$.
\end{abstract}

Keywords: body protein mobilization, body fat mobilization, dietary protein intake, milk composition, lactation

\section{Implications}

Feeding excessive dietary protein to sows increases nitrogen excretion into the environment. Hence, it is important that the protein provision matches the actual amino acid requirement of the sow. This study showed that increased protein intake of hyper-prolific lactating sows prevents excessive BW loss and decreases body protein mobilization, as the extra dietary protein was utilized for milk production. Minimizing the body mobilization can ensure better performance of sows in the following reproductive cycle. The higher milk yield and nutrient concentrations resulted in higher litter gains, which is of great economic importance to the pig producer.

\footnotetext{
† E-mail: avst@sund.ku.dk
}

\section{Introduction}

Sows have become larger and leaner during the last decades, and their milk yield has increased (Hansen et al., 2012) to cover the requirement of the large litters. These tremendous changes probably have increased the dietary requirement of protein and amino acids of the sow. For many years focus has been on determining the requirement of single amino acids, especially lysine, and not the requirement of balanced CP. The supply of protein above the requirement will cause deamination of the surplus amino acids and increased excretion of $\mathrm{N}$ into the environment (Hansen et al., 2014; Huber et al., 2015). In another part (Strathe et al., 2017a) of the current study, the dietary standardized ileal digestible (SID) CP concentration for maximizing litter gain was determined to be $135 \mathrm{~g} / \mathrm{kg}$. Litter gain is regarded as an important determinant of nutrient requirements of lactating sows (Trottier et al., 2015). However, it is also important to 
understand how the dietary provision of $\mathrm{CP}$ influences the mobilization of body tissues and milk production when determining the requirement of lactating sows. Sows often turn catabolic in order to maintain their milk production (Strathe et al., 2017b). Under-supplying dietary protein can cause a high mobilization of body protein (King et al., 1993; Mejia-Guadarrama et al., 2002), since milk production has a very high priority. Depleted body protein pools must be restored during the following gestation, which is energetically unfavourable (Dourmad et al., 1996; Bender, 2012) and should therefore be avoided. The extent of the catabolic state will be reflected in changes in body composition, plasma metabolite concentrations and milk production (Dourmad et al., 1998). Measurements of plasma urea N (PUN) concentrations, milk composition and body composition can be used as alternative markers for the optimum SID CP (Coma et al., 1996; Yang et al., 2000), because it is not given that the metabolism of the sow is optimized at the same dietary SID CP concentration as the litter gain.

Hence, the objective of this experiment was to estimate the dietary SID CP requirement of lactating sows using litter gain as the main determinant supported by measurements on several traits reflecting sow metabolism. It was hypothesized that increased dietary protein provision would decrease body protein mobilization and improve milk production through increased yield and nutrient concentrations as well as affect sow plasma concentrations of metabolites related to protein and fat metabolism.

\section{Material and methods}

This experiment was carried out on a subsample of 92 sows from a larger trial with 544 sows (Strathe et al., 2017a).

\section{Treatments, animals and housing}

The study was conducted in a commercial piggery using a total of 92 parity 2 and 3 sows (Danish Landrace $\times$ Danish Yorkshire, DanAvl) inseminated with Duroc semen (Hatting $\mathrm{KS}$, Horsens, Denmark). The animals were studied from 4 days prepartum $(-4.1 \pm 1.6)$ to 24 days postpartum (24.4 \pm 1.2$)$ when piglets were weaned. Sows were randomly allocated to one out of six dietary treatments with increasing dietary provision of SID protein (Table 1) and stratified for parity in a complete block design from day 2 postpartum. Diets were formulated to be isoenergetic on net energy basis (EvaPig $\left.{ }^{\circledR}, 2008\right)$. Sows were fed using a SpotMix feeding system (Schauer Agrotronic, Prambachkirchen, Austria), and meals for each sow were weighed and registered by the feeding system. From day 4 prepartum to day 2 postpartum all sows were fed the same commercial formulated lactation diet based on wheat, soybean meal and sugar beet pulp complying with Danish recommendations (Tybirk et al., 2014). From day 2 to day 10 of lactation, sows were fed twice daily, and from day 10 onwards, sows were fed three times per day. The sows were fed $2.3 \mathrm{~kg}$ from day 2 postpartum, and feed allowance was gradually increased to $8.4 \mathrm{~kg}$ at day 17 . Sows had drinking nipples in the trough and free access to water. Feed residuals were not recorded, but feed allowance was adjusted for individual sows daily, and the feed allowances mentioned above were used as maximum for the sows, so some sows would consume less.

Each week a batch of six sows was selected for the experiment, moved to the farrowing unit day 4 prepartum and placed in individual farrowing crates. Twenty-four hours postpartum (day 2) the litters of the experimental sows were standardized to 14 piglets (average piglet weight $1.76 \pm 0.24 \mathrm{~kg}$ ). Apart from the observations made in the experiment all animals were managed according to the general routines of the herd. Health was monitored by the stock personnel, and normal herd practices for management, treatments and vaccinations were followed. When dead or very weak piglets were removed, the date and weight of the excluded piglets were recorded.

\section{Data collection, measurements and chemical analyses} Information on the collection of feed samples and analyses is given in Strathe et al. (2017a). On 544 sows, BW and back fat (BF) thickness were measured at day 2 postpartum and at weaning, and litter weight was recorded at litter standardization and at weaning (Strathe et al., 2017a).

On 70 sows (10 to 12 per dietary treatment), blood, urine and milk samples were collected. Blood samples were collected in $10 \mathrm{ml}$ EDTA tubes (BD Vacutainer, Plymouth, UK) from the jugular vein at days $-4,3,10,17$, and 24 postpartum $4 \mathrm{~h}$ after the morning feeding. Samples were placed on ice and centrifuged for $10 \mathrm{~min}(1560 \times \mathbf{g})$ at room temperature, and plasma was then harvested and stored at $-20^{\circ} \mathrm{C}$ in $1.5-\mathrm{ml}$ microcentrifuge tubes (Kruuse, Langeskov, Denmark) until analysis. Plasma was analysed for concentrations of PUN, creatinine, glucose, lactate and nonesterified fatty acids (NEFA), triglycerides, cholesterol, total protein, albumin, alanine amino transferase (ALT), aspartate amino transferase (AST), gamma-glutamyl transferase (GGT) and alkaline phosphatase (Advia 1800 Chemistry System; Siemens, Denmark).

Milk samples were collected on days 3, 10 and 17 postpartum. Piglets were removed from the sow for at least $30 \mathrm{~min}$, and $2 \mathrm{ml}$ oxytocin (Oxytocin 'Intervet' Vet, $10 \mathrm{IE} / \mathrm{ml}$; Intervet International B. V., Boxmeer, Netherlands) was injected intramuscularly to induce milk letdown. Milk was sampled from four to five teats and stored in $50-\mathrm{ml}$ tubes (Sarstedt, Nümbrecht, Germany) at $-20^{\circ} \mathrm{C}$ until analysis for DM, lactose, fat and true protein (MilcoScan FT2, Foss Electric, Denmark).

On another subsample of 60 sows ( 10 per treatment), body water content was measured by the deuterium oxide $\left(D_{2} \mathbf{O}\right)$ dilution technique (Theil et al., 2002) on days 3 and 24 postpartum. An initial blood sample was drawn from the jugular vein into a 4-ml lithium-heparinized tube (BD Vacutainer, Plymouth, UK) just before $\mathrm{D}_{2} \mathrm{O}$ injection, and then $5 \mathrm{~h}$ after injection with $\mathrm{D}_{2} \mathrm{O}$, a second sample was taken. A dose of $0.2 \mathrm{ml}\left(10 \%\right.$ solution of $\mathrm{D}_{2} \mathrm{O}$; Sigma Aldrich, Brøndby, Denmark) per kg BW was injected i.m. in the neck 
Table 1 Dietary composition (as-fed) of diets fed to sows from day 2 postpartum to weaning

\begin{tabular}{|c|c|c|c|c|c|c|}
\hline & \multicolumn{6}{|c|}{ Diet } \\
\hline & 1 & 2 & 3 & 4 & 5 & 6 \\
\hline \multicolumn{7}{|l|}{ Ingredient (\%) } \\
\hline Barley & 46.0 & 44.8 & 43.8 & 42.8 & 41.4 & 40 \\
\hline Wheat & 36.2 & 35.0 & 34.0 & 33.0 & 31.6 & 30.2 \\
\hline Soy bean meal & 8.4 & 11.1 & 13.4 & 15.7 & 18.9 & 22.1 \\
\hline Wheat bran & 1.80 & 1.44 & 1.14 & 0.84 & 0.42 & 0.00 \\
\hline Sugar beet pellets & 2.00 & 2.00 & 2.00 & 2.00 & 2.00 & 2.00 \\
\hline Vegetable oil $^{1}$ & 1.73 & 1.76 & 1.78 & 1.80 & 1.84 & 1.87 \\
\hline Monocalcium phosphate & 1.15 & 1.13 & 1.11 & 1.10 & 1.07 & 1.05 \\
\hline Limestone & 1.63 & 1.62 & 1.61 & 1.61 & 1.59 & 1.58 \\
\hline Salt & 0.52 & 0.52 & 0.52 & 0.52 & 0.52 & 0.52 \\
\hline L-Lys $(65 \%)$ & 0.34 & 0.34 & 0.34 & 0.34 & 0.34 & 0.33 \\
\hline L-Thr & 0.06 & 0.07 & 0.07 & 0.07 & 0.08 & 0.08 \\
\hline DL-Met & 0.03 & 0.04 & 0.05 & 0.06 & 0.07 & 0.08 \\
\hline L-Val & 0.00 & 0.01 & 0.01 & 0.01 & 0.02 & 0.02 \\
\hline Vitamin and mineral premix ${ }^{2}$ & 0.18 & 0.19 & 0.19 & 0.19 & 0.20 & 0.20 \\
\hline Phyzyme $X \mathrm{P}^{3}$ & 0.01 & 0.01 & 0.01 & 0.01 & 0.01 & 0.01 \\
\hline Microgrits & 0.05 & 0.05 & 0.05 & 0.05 & 0.05 & 0.05 \\
\hline \multicolumn{7}{|l|}{ Composition (calculated) } \\
\hline DM $(\%)$ & 86.3 & 86.4 & 86.5 & 86.6 & 86.7 & 86.8 \\
\hline $\mathrm{CP}(\mathrm{g} / \mathrm{kg})$ & 120 & 130 & 139 & 147 & 159 & 171 \\
\hline Starch $(\mathrm{g} / \mathrm{kg})$ & 452 & 440 & 429 & 419 & 405 & 391 \\
\hline Soluble fibre $(\mathrm{g} / \mathrm{kg})$ & 42 & 43 & 43 & 44 & 45 & 46 \\
\hline Insoluble fibre $(\mathrm{g} / \mathrm{kg})$ & 126 & 126 & 126 & 126 & 126 & 126 \\
\hline SID 4 Lys $(\mathrm{g} / \mathrm{kg})$ & 5.8 & 6.5 & 7.0 & 7.5 & 8.3 & 9.0 \\
\hline Energy (MJ NE/kg) & 7.9 & 7.9 & 7.9 & 8.0 & 8.0 & 8.0 \\
\hline \multicolumn{7}{|l|}{ Composition (analysed) ${ }^{5}$} \\
\hline $\mathrm{CP}(\mathrm{g} / \mathrm{kg})$ & 128.4 & 138.0 & 146.4 & 154.6 & 166.3 & 177.9 \\
\hline Lys (g/kg) & 7.04 & 7.71 & 8.26 & 8.82 & 9.60 & 10.38 \\
\hline Met $(\mathrm{g} / \mathrm{kg})$ & 2.21 & 2.41 & 2.58 & 2.75 & 2.98 & 3.22 \\
\hline Thr (g/kg) & 4.80 & 5.26 & 5.64 & 6.02 & 6.55 & 7.08 \\
\hline $\operatorname{Trp}(g / k g)$ & 1.61 & 1.75 & 1.86 & 1.97 & 2.13 & 2.29 \\
\hline Leu $(\mathrm{g} / \mathrm{kg})$ & 8.48 & 9.28 & 9.95 & 10.6 & 11.6 & 12.5 \\
\hline Ile (g/kg) & 4.51 & 5.00 & 5.41 & 5.82 & 6.39 & 6.96 \\
\hline His $(g / k g)$ & 2.92 & 3.19 & 3.41 & 3.63 & 3.95 & 4.26 \\
\hline Phe $(\mathrm{g} / \mathrm{kg})$ & 5.81 & 6.33 & 6.77 & 7.20 & 7.81 & 8.42 \\
\hline Val $(\mathrm{g} / \mathrm{kg})$ & 5.74 & 6.21 & 6.60 & 6.99 & 7.53 & 8.08 \\
\hline SID CP $(g / k g)$ & 104.3 & 113.3 & 120.9 & 128.5 & 139.2 & 150.0 \\
\hline SID Lys ${ }^{6}(\mathrm{~g} / \mathrm{kg})$ & 5.85 & 6.46 & 6.98 & 7.52 & 8.25 & 8.98 \\
\hline SID $\operatorname{Met}^{6}(\mathrm{~g} / \mathrm{kg})$ & 1.91 & 2.12 & 2.28 & 2.45 & 2.68 & 2.91 \\
\hline SID Thr ${ }^{6}(\mathrm{~g} / \mathrm{kg})$ & 3.86 & 4.29 & 4.64 & 4.98 & 5.47 & 5.99 \\
\hline SID $\operatorname{Trp}^{6}(\mathrm{~g} / \mathrm{kg})$ & 1.30 & 1.44 & 1.54 & 1.64 & 1.79 & 1.94 \\
\hline SID Leu ${ }^{6}(\mathrm{~g} / \mathrm{kg})$ & 6.92 & 7.65 & 8.25 & 8.86 & 9.70 & 10.6 \\
\hline SID $\| e^{6}(\mathrm{~g} / \mathrm{kg})$ & 3.68 & 4.13 & 4.50 & 4.88 & 5.40 & 5.92 \\
\hline SID His ${ }^{6}(\mathrm{~g} / \mathrm{kg})$ & 2.39 & 2.82 & 2.85 & 3.05 & 3.34 & 3.63 \\
\hline SID Phe ${ }^{6}(\mathrm{~g} / \mathrm{kg})$ & 4.84 & 5.32 & 5.73 & 6.13 & 6.70 & 7.26 \\
\hline SID Val ${ }^{6}(\mathrm{~g} / \mathrm{kg})$ & 4.52 & 4.97 & 5.35 & 5.71 & 9.12 & 6.75 \\
\hline
\end{tabular}

Lys=lysine; Met=methionine; Thr=threonine; Trp=tryptophan; Leu=leucine; lle=isoleucine; His=histidine; Phe=phenylalanine; Val=valine; SID=standardized ileal digestible.

1 Leci E Basic, Evilec ApS, Sandbjergvej 26, 6000 Kolding, Denmark.

2 Provided per kilogram of the diet: $8900 \mathrm{IU}$ vitamin A; $890 \mathrm{IU}$ vitamin D3; $167 \mathrm{mg}$ DL-alfa-tocopherol, $4.24 \mathrm{mg}$ vitamin K3;2.23 mg vitamin B1; $5.57 \mathrm{mg}$ vitamin B2; 3.34 $\mathrm{mg}$ vitamin B6; $0.02 \mathrm{mg}$ vitamin B12; $16.70 \mathrm{mg}$ D-pantothenic acid; $22.26 \mathrm{mg}$ niacin; $1.67 \mathrm{mg}$ folic acid; $89.04 \mathrm{mg}$ iron (FeSO $\left.)_{4}\right) ; 13.00 \mathrm{mg}$ copper (CuSO 4$) ; 44.52 \mathrm{mg}$ manganese (MnO); $0.22 \mathrm{mg}$ iodine $\left(\mathrm{Ca}\left(\mathrm{IO}_{3}\right)_{2}\right) ; 0.37 \mathrm{mg}$ selenium $\left(\mathrm{Na}_{2} \mathrm{SeO}_{3}\right)$.

3 Phyzyme XP provided 500 phytase activity (FTU) per kilogram of diet (Danisco Animal Nutrition DuPont, Marlborough, UK).

${ }^{4}$ SID values used in diet formulation were from Pedersen and Boisen (2002).

${ }^{5}$ Feed samples were sampled regularly during the experimental period, and 12 feed samples were analysed per dietary treatment.

${ }^{6}$ Calculated from the analysed composition and digestibilities used when formulating the diets. 
of the sow. The exact amount of $D_{2} O$ injected was determined by weighing the syringe before and after injection. The blood samples were centrifuged for $10 \mathrm{~min}(1560 \times \mathrm{g})$ at room temperature, and plasma was then recovered and stored in 1.5-ml microcentrifuge tubes (Kruuse, Langeskov, Denmark) at $-20^{\circ} \mathrm{C}$ until analysis. The total $\mathrm{D}_{2} \mathrm{O}$ space was determined as described by Theil et al. (2002).

\section{Calculations and statistical analysis}

Calculations and statistical analyses were carried out using the statistical software R ( $R$ Core Team, Vienna, Austria) with the individual sow regarded as the experimental unit. Average daily gain (ADG) of the litter was calculated from litter size and weight at standardization and at weaning. Weights of dead piglets or piglets removed from the litter during the experiment were included in the litter gain. Milk yield was estimated from ADG of the litter and litter size (data not shown) using equations by Hansen et al. (2012). The content of body water was estimated based on the measured concentrations of $D_{2} O$ in plasma. From body water, $B F$ and BW, the body protein, fat and ash contents were estimated using equations by Rozeboom et al. (1994). In the analysis of the dose-response data, the dietary SID CP concentrations were used as an explanatory variable. Based on the recordings of individual daily feed intakes of the sows, chemical analysis of dietary composition, and digestibility coefficients of CP of the six diets, an average dietary SID $\mathrm{CP}$ concentration was calculated for the individual sow.

Data were fitted using a mixed-effects model in ANOVA form using the nlme package in $R$ to describe the effect of the six dietary treatments. Feed intake, sow BW and BF, sow body composition and changes in body composition, and litter weight were analysed using model (1). The interaction between diet and parity was tested, but the interaction and the effect of parity were not significant and therefore eliminated in the final model:

$$
Y_{i j k}=\mu+\alpha_{i}+\beta_{j}+\varepsilon_{i j k}
$$

where $Y_{i j k}$ is the response variable measured on the $k$ th sow $\left(k=1, \ldots, n_{i j}\right)$ in the $j$ th block $(j=1,2, \ldots, 16)$ receiving the $i$ th diet $(i=1, \ldots, 6)$. Here $\mu$ is the overall mean, $\alpha_{i}$ is the fixed effect of diet, $\beta_{j}$ is the random effect of block that was assumed to be $N\left(0, \sigma_{B}^{2}\right)$, and $\varepsilon_{i j k}$ is the random error component, which was assumed to be $N\left(0, \sigma_{e}^{2}\right)$.

When analysing milk yield and composition, daily secretions and concentrations of plasma metabolites, a repeated-measures model was fitted to data. The threeway interaction between diet, parity and day were included in model (2), but none of the three-way or two-way interactions and the effect of parity were significant and therefore excluded from the final model:

$$
Y_{i j k l}=\mu+\alpha_{i}+\beta_{j}+\gamma_{k}+\nu_{l}+\varepsilon_{i j k l}
$$

where $Y_{i j k l}$ is the response variable measured on the $/$ th sow $\left(I=1, \ldots, n_{i j k}\right)$ in the $k$ th block $(k=1,2, \ldots, 16)$ receiving the th $^{\text {diet }}(i=1, \ldots, 6)$ on the $j$ th day postpartum $(j=1, \ldots, 5)$. Here $\mu$ is the overall mean, $\alpha_{i}$ is the fixed effect of diet, $\beta_{j}$ is the fixed effect of day postpartum, $\gamma_{k}$ is the random effect of block that was assumed to be $N\left(0, \sigma_{B}^{2}\right), \nu$, is the random effect of sow that was assumed to be $N\left(0, \sigma_{S}^{2}\right)$, and $\varepsilon_{i j k l}$ is the random error component that was assumed to be $N\left(0, \sigma_{e}^{2}\right)$. Plasma concentrations of lactate, NEFA, alkaline phosphatase and GGT were log-transformed, because of lacking variance homogeneity. Results are given as least squares means and SE. Log-transformed data were back-transformed and given as least squares means and $95 \%$ confidence interval (CI). Statistical significance was declared at $P<0.05$ and tendency at $P<0.10$.

All response variables were analysed using either a linear dose-response function or nonlinear dose-response function, being the linear broken-line and quadratic broken-line. Here dietary CP concentration was treated as a continuous variable. The nonlinear dose-response models were fitted using nonlinear mixed-effects models, where the random effect of block was incorporated into the plateau parameter of the models as described by Robbins et al. (2006). Taking the linear plateau model as an example, then the nonlinear mixed-effect model was formulated as:

$$
y_{i j}=\left\{\begin{array}{c}
k *\left(R-C P_{i j}\right) ; C P_{i j}<R \\
y_{\max }+b_{i} ; C P_{i j}>R
\end{array}+e_{i j}\right.
$$

where $y_{i j}$ denotes response variable for the jth sow in the ith block. Population parameters are the slope $k$ in response to dietary $C P_{i j}$ below the requirement $R$ and $y_{\max }$ is plateau level, where the dietary $C P_{i j}$ is not limiting sow performance. The random effect $b_{i}$ captures the block-to-block variation in sow performance and is assumed to be $N\left(0, \sigma_{B}^{2}\right)$, and $\varepsilon_{i j}$ is the random error component, which was assumed to be $N\left(0, \sigma_{e}^{2}\right)$

The model output was evaluated using three criteria: (1) comparison of Akaike Information Criteria and -2 log likelihood fit statistics for nested models, (2) models with breakpoint outside the range of the tested SID CP concentrations was regarded inappropriate, and (3) evaluation of visual fit to data. The nonlinear models were compared to the linear model using the abovementioned criteria. However, only results of variables with a significant effect of dietary $C P$ concentration are shown in the Results section. All data were used to fit the models, but in Figures 1 and 2 the least square means for the six groups are also presented together with the best model as described above.

When the ANOVA revealed that there was no difference between sampling days ( $P>0.10)$, data for these days were pooled. For PUN, data from days 3 and 10, and days 17 and 24 , respectively, were combined. Data for plasma albumin at days 17 and 24 were united. For GGT, data from days 3, 10, 17 and 24 were pooled.

\section{Results}

Results for the model with the best fit to data according to the criteria given above are presented. The nonlinear models 


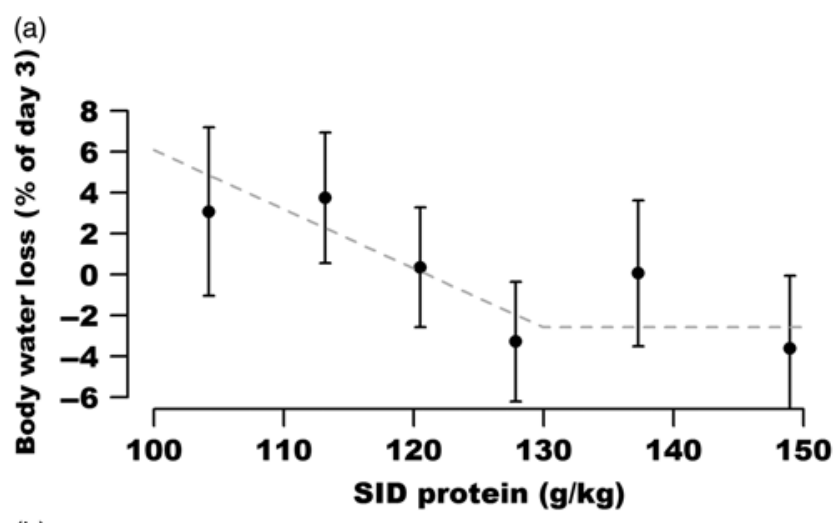

(b)

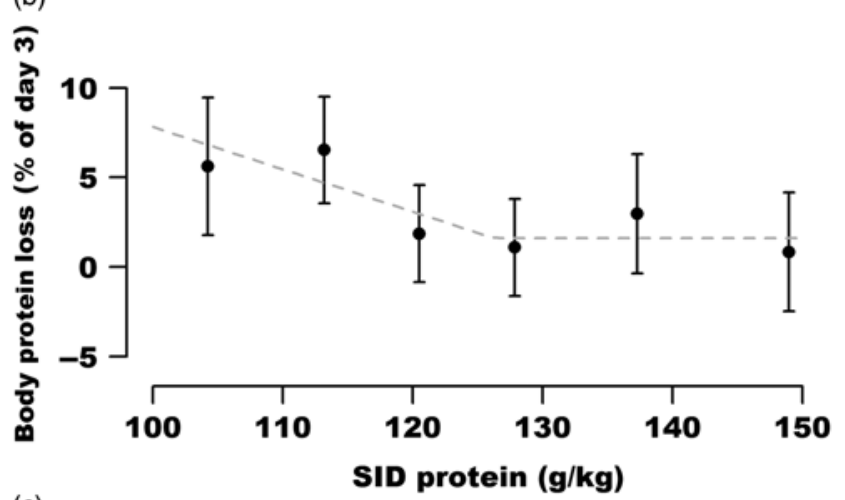

(c)

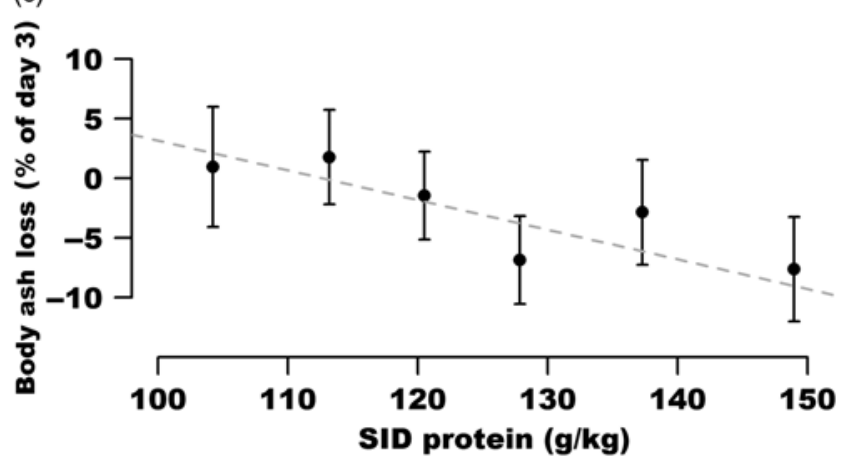

Figure 1 Changes in the contents of body water, protein and ash from day 3 to day 24 postpartum with increased standard ilea digestible (SID) dietary protein. The content of body water was determined using the deuterium dilution technique (Theil et al., 2002). Body protein and ash were estimated from body water, BW and back fat thickness. The loss is given as the percentage of tissue mass at day 3 . Data were fitted using linear regression, linear broken-line and quadratic broken-line models using nonlinear mixedeffects models. The model with the best fit is presented in the figure. Data points in the figures are least square means and SE of the six dietary groups, and the linear broken-line model or the linear regression model using data of individual sows are also presented. (a) Body water loss decreased linearly $(-0.3 \times($ SID CP -130$) \times($ SID CP $\leq 130)-2.5)$ until $130 \mathrm{~g} \mathrm{SID} \mathrm{CP/kg} \mathrm{at} \mathrm{a}$ loss of $2.5 \%(P<0.001)$, (b) body protein decreased linearly $(-0.2 \times$ (SID CP - 128) $\times($ SID CP $\leq 128)+1.5)$ until $128 \mathrm{~g}$ SID CP/kg at a loss of $1.5 \%$ $(P<0.001)$ and $(c)$ body ash loss decreased linearly $(Y=25.5-0.23 \times$ SID CP $(\mathrm{g} / \mathrm{kg}) ; P<0.001)$. Negative values indicate a gain.

were compared to the linear regression model, and for the change in body water and protein, concentrations of milk lactose and CP and PUN, the linear broken-line model was chosen over other models. For plasma concentrations of albumin, GGT and ALT, change in body ash and concentration of milk fat, the linear regression model was the best fit to data.

\section{Diets and sow performance}

The concentration of protein was slightly higher in the six diets than planned, because wheat and barley had a higher content of crude protein than expected in the feed formulation. The average daily feed intake of the sows was similar in all groups (Table 2; $P=0.78$ ), and as planned, the daily intake of protein increased with increasing SID CP concentrations of the six diets $(P<0.001)$.

Litter size (12.8 \pm 1.2 piglets) at weaning was unaffected by dietary SID CP concentration, whereas ADG of the litters $\left(0.01 \times(S I D C P-135) \times(S I D C P \leq 135)+2.53_{\text {first parity }}\right.$ or 3.07 multiparity $)$ and BF loss $(-0.03 \times($ SID CP -127$) \times($ SID $\mathrm{CP} \leq 127)-2.97)$ of sows increased and BW loss $(0.007$ $\times(S I D C P-143) \times(S I D C P \leq 143)-0.58)$ decreased with increasing dietary SID CP $(P<0.001$; data not shown). For a detailed description of these results, see Strathe et al. (2017a).

\section{Milk composition and nutrient output}

Milk composition was only affected by dietary SID CP at day 17 of lactation. Milk fat and DM contents decreased throughout lactation $(P<0.001)$, and at day 17 , milk fat concentration increased linearly with increasing dietary SID CP $(P<0.05)$, as an increase by $1 \mathrm{~g}$ SID CP/kg increased the fat content with 0.02 percentage units. Milk lactose concentration on day 17 of lactation decreased with increasing dietary SID CP until a breakpoint at $124 \mathrm{~g}$ SID CP $/ \mathrm{kg}$ $(5.3 \% ; P<0.001)$, but the lactose concentration of the milk did not change throughout lactation $(P=0.15)$. Milk protein concentration decreased from day 3 to day 10 of lactation $(P<0.001)$. The concentration of milk protein on day 17 increased until a breakpoint at $136 \mathrm{~g} \mathrm{SID} \mathrm{CP/kg} \mathrm{(5.0 \% ;}$ $P<0.001)$. Results of milk yield and composition are given in Table 3.

\section{Body composition of sows}

Results of body composition measurements are given in Table 4 and Figure 1. The loss of body water from day 3 of lactation to weaning decreased with increasing dietary SID CP until a dietary SID CP of $130 \mathrm{~g} / \mathrm{kg}(P<0.001)$, and a similar pattern was seen for the loss of protein, which reached a breakpoint at $128 \mathrm{~g} \mathrm{SID} \mathrm{CP/kg}(P<0.001)$. The body ash loss declined linearly with increasing dietary SID CP $(P<0.01)$, whereas the change in body fat was unaffected by dietary treatment $(P=0.41)$.

\section{Plasma metabolites}

As expected, the concentrations of metabolites in plasma were similar for all groups at day $-4(P>0.05)$. The concentrations of PUN increased with increasing dietary SID CP intake (Figure 2; $P<0.001$ ). The concentrations of PUN were similar at days 3 and 10 , and at days 17 and 24, respectively, and there was an interaction between diet and stage of lactation $(P<0.05)$. In early lactation (day $3+$ day 10$)$, PUN increased linearly after the breakpoint at $139 \mathrm{~g}$ SID $\mathrm{CP} / \mathrm{kg}$ at a concentration at $3.8 \mathrm{mmol} / \mathrm{l}$, but in late lactation (day 17 + day 24), PUN increased linearly after a breakpoint 
Strathe, Bruun, Tauson, Theil and Hansen

(a)

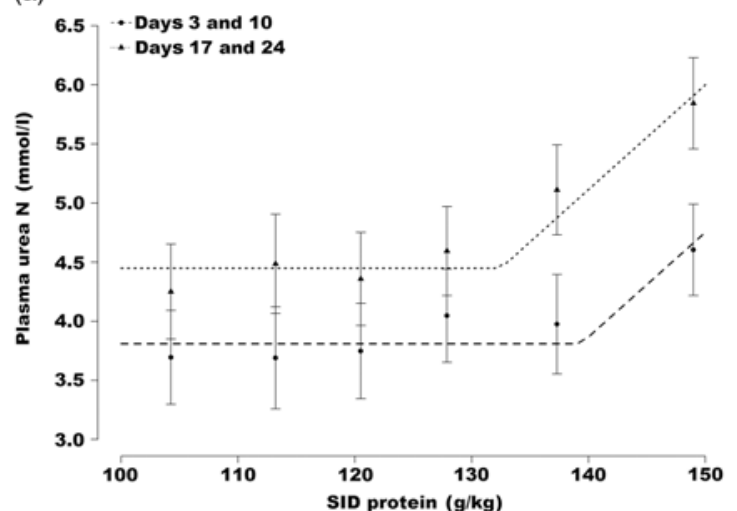

(c)

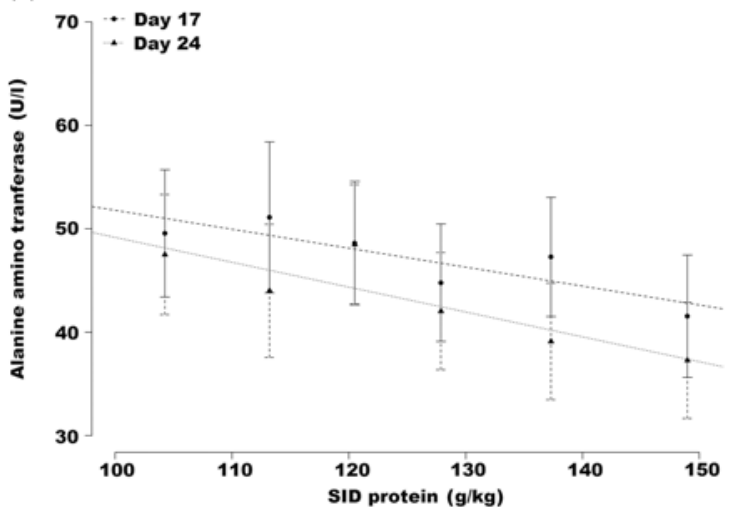

(b)

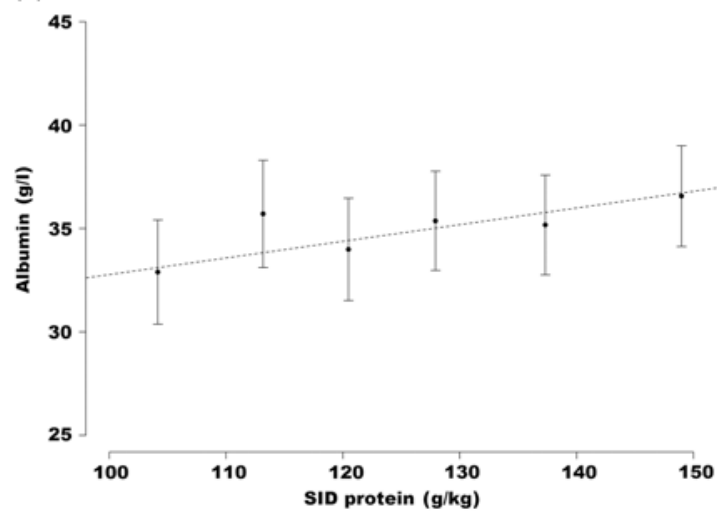

(d)

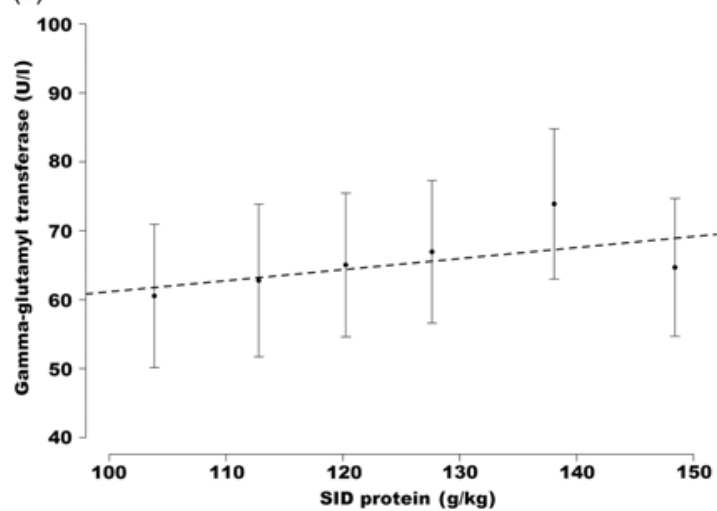

Figure 2 Effect of dietary standardized ileal digestible (SID) CP concentrations on the plasma concentrations of metabolites. Data were fitted using linear regression, linear broken-line and quadratic broken-line models using nonlinear mixed-effects models. The model with the best fit is presented in the figure. Data points in the figures are least square means and SE of the six dietary groups, and the linear broken-line model or the linear regression model using data of individual sows are also presented. (a) Urea $\mathrm{N}$ was at a stable level until a linear increase from $139 \mathrm{~g} \mathrm{SID} \mathrm{CP} / \mathrm{kg}(0.09 \times(\mathrm{SID} C P-139) \times(\mathrm{SID} C P \geq 139)+3.8)$ in early lactation (day $3+$ day 10$)$ and at a stable level until a linear increase from $133 \mathrm{~g} \mathrm{SID} \mathrm{CP/kg}(0.09 \times(\mathrm{SID} C P-133) \times($ SID CP $\geq 133)+4.5)$ in late (day $17+$ day 24$)$ lactation, respectively $(P<0.001)$; (b) albumin increased linearly $(Y=27.7+0.06 \times \operatorname{SID~CP}(\mathrm{kg} /$ day $))$ at late (day $17+$ day 24$)$ lactation $(P<0.05)$; (c) alanine amino transferase increased linearly at day $17(Y=72.8-0.23 \times \operatorname{SID~CP}(\mathrm{g} / \mathrm{kg}) ; P<0.01)$ and day $24(Y=80.1-0.26 \times \operatorname{SID} C P(\mathrm{~g} / \mathrm{kg}) ; P<0.05)$ of lactation and (d) gamma-glutamyl transferase (days $3+10+17+24)$ increased linearly $(Y=31.2+0.05 \times$ SID CP $(\mathrm{g} / \mathrm{kg}))$ with increasing dietary SID CP $(P<0.05)$, respectively.

at $133 \mathrm{~g} \mathrm{SID} \mathrm{CP} / \mathrm{kg}(P<0.001$, Figure 2$)$ at a concentration of $4.5 \mathrm{mmol} / \mathrm{l}$. Albumin concentration increased linearly in late lactation with increasing dietary SID CP (day 17 + day 24; $P<0.05)$, and GGT also increased linearly $(P<0.05)$ at all stages of lactation, whereas the concentration of ALT decreased linearly at day $17(P<0.01)$ and day $24(P<0.05)$ with increasing dietary SID CP concentration (Figure 2).

The dietary SID CP did not affect plasma concentrations of glucose, lactate, NEFA, triglycerides, cholesterol, creatinine, total protein, AST and alkaline phosphatase $(P>0.05$; data not shown), whereas all of the abovementioned metabolites were affected by day $(P<0.001$; data not shown) except for lactate $(P>0.05)$.

\section{Discussion}

The current study estimated the SID CP requirement of hyperprolific lactating sows using litter gain as the main determinant supported by measurements on several traits of sow metabolism. Based on the average feed intake and the SID CP concentration of $135 \mathrm{~g} / \mathrm{kg}$ (Strathe et al., 2017a), the daily requirement for optimal litter ADG was estimated to be $850 \mathrm{~g}$ SID CP/day. The $850 \mathrm{~g}$ SID CP/day found in the current study was considerably higher than the $700 \mathrm{~g}$ SID CP/day estimated in the NRC model (National Research Council, 2012) and slightly lower than the $880 \mathrm{~g}$ SID CP/day ( $\pm 70 \mathrm{~g} /$ day) estimated in the requirement model by Strathe et al. (2015). The largest difference between the two models is the equation used to determine milk production: the one used by NRC (2012) is based on weigh-suckle-weigh data, which underestimates milk yield and thereby estimates a lower requirement (Hansen et al., 2012).

\section{Milk production}

The main purpose of the lactating sow is to produce milk with a nutrient composition and yield that matches the requirements of the piglets. Dietary SID CP concentration did only affect milk nutrient concentration and nutrient yield on day 17 of lactation. The improved ADG of the litter with increasing dietary SID CP most likely was a combined result of increased milk yield throughout lactation and an increased concentration of protein at peak lactation. Many studies have 
Table 2 Effect of increased dietary standardized ileal digestible (SID) CP on sow and piglet performance $(n=92)^{1}$

\begin{tabular}{lcccccccc}
\hline \hline & \multicolumn{9}{c}{ SID CP (g/kg) } & & P-value \\
\cline { 2 - 6 } & 104.3 & 113.3 & 120.9 & 128.5 & 139.2 & 150.0 & SE & Diet \\
\hline Parity & 2.7 & 2.7 & 2.7 & 2.7 & 2.7 & 2.7 & 0.12 & 0.95 \\
Feed intake (kg/day) & 6.31 & 6.24 & 6.52 & 6.62 & 6.42 & 6.34 & 0.22 & 0.78 \\
Protein intake (g/day) & 808 & 861 & 951 & 1019 & 1053 & 1122 & 33.9 & $<0.001$ \\
SID protein intake (g/day) & 656 & 707 & 785 & 847 & 882 & 945 & 28.1 & $<0.001$ \\
Lysine intake (g/day) & 42.1 & 46.4 & 51.9 & 57.1 & 60.3 & 65.0 & 2.10 & $<0.001$ \\
SID lysine intake (g/day) & 35.7 & 39.8 & 44.7 & 49.4 & 52.5 & 56.8 & 1.81 & $<0.001$ \\
Litter weight day 2 (kg) & 24.9 & 26.4 & 24.1 & 24.9 & 23.7 & 24.8 & 1.08 & 0.47 \\
BW sow day 2 (kg) & 239 & 251 & 252 & 248 & 253 & 248 & 6.30 & 0.31 \\
Back fat sow day 2 (mm) & 13.4 & 14.5 & 14.2 & 14.4 & 14.4 & 13.7 & 0.72 & 0.44 \\
Litter weight day 25 (kg) & 85.1 & 92.6 & 93.8 & 93.7 & 93.0 & 96.3 & 4.88 & 0.31 \\
BW sow day 25 (kg) & 221 & 225 & 227 & 235 & 237 & 240 & 6.80 & 0.05 \\
Back fat sow day 25 (mm) & 11.7 & 11.9 & 11.8 & 12.3 & 11.1 & 10.6 & 0.71 & 0.29 \\
\hline \hline
\end{tabular}

${ }^{1}$ The interaction of Diet $\times$ Parity was not significant $(P>0.05)$.

Table 3 Effect of increased dietary standardized ileal digestible (SID) CP on milk yield, composition and nutrient output of lactating sows ${ }^{1}$

\begin{tabular}{|c|c|c|c|c|c|c|c|c|c|c|}
\hline & \multirow[b]{2}{*}{$n$} & \multicolumn{6}{|c|}{ SID protein (g/kg) } & \multirow[b]{2}{*}{ SE } & \multicolumn{2}{|c|}{$P$-values } \\
\hline & & 104.3 & 113.3 & 120.9 & 128.5 & 139.2 & 150.0 & & Diet & Day \\
\hline Milk yield² (kg/day) & 92 & 10.5 & 11.2 & 11.5 & 11.3 & 11.4 & 11.4 & 0.49 & 0.26 & - \\
\hline \multicolumn{11}{|l|}{ Milk composition } \\
\hline DM (\%) & & & & & & & & & $<0.05$ & $<0.001$ \\
\hline Day 3 & 37 & 17.9 & 18.9 & 18.5 & 19.2 & 19.0 & 18.4 & 0.62 & & \\
\hline Day 10 & 56 & 17.2 & 18.6 & 18.1 & 17.9 & 18.9 & 17.8 & 0.50 & & \\
\hline Day 17 & 64 & 16.5 & 17.2 & 17.3 & 17.1 & 17.8 & 17.6 & 0.47 & & \\
\hline Lactose (\%) & & & & & & & & & $<0.10$ & 0.15 \\
\hline Day 3 & 38 & 5.33 & 5.18 & 5.10 & 5.45 & 4.99 & 5.05 & 0.27 & & \\
\hline Day 10 & 57 & 5.29 & 5.11 & 5.66 & 5.76 & 5.14 & 5.09 & 0.19 & & \\
\hline Day 17 & 59 & 5.58 & 5.47 & 5.22 & 5.47 & 5.44 & 5.15 & 0.19 & & \\
\hline Fat (\%) & & & & & & & & & 0.14 & $<0.001$ \\
\hline Day 3 & 38 & 7.36 & 8.13 & 8.69 & 8.70 & 8.05 & 7.58 & 0.67 & & \\
\hline Day 10 & 57 & 6.79 & 7.73 & 7.43 & 7.46 & 7.54 & 7.20 & 0.43 & & \\
\hline Day 17 & 60 & 6.06 & 6.49 & 6.35 & 6.63 & 7.02 & 6.91 & 0.43 & & \\
\hline Protein (\%) & & & & & & & & & $<0.05$ & $<0.001$ \\
\hline Day 3 & 36 & 5.13 & 5.54 & 5.62 & 5.80 & 5.59 & 5.46 & 0.23 & & \\
\hline Day 10 & 56 & 4.66 & 5.02 & 4.99 & 4.97 & 5.08 & 4.95 & 0.16 & & \\
\hline Day 17 & 61 & 4.61 & 4.72 & 4.71 & 4.89 & 5.10 & 4.94 & 0.15 & & \\
\hline
\end{tabular}

1 The interactions of Diet $\times$ Day and Diet $\times$ Parity and the effect of Parity were not significant $(P>0.05)$.

${ }^{2}$ Estimated from equation by Hansen et al. (2012).

proven it difficult to increase the concentration of protein in sow milk above $5.0 \%$ to $5.5 \%$ (Hurley, 2015). The true milk protein content at the breakpoint on day 17 reached only $5.0 \%$, which was not unusually high compared to other studies (Guan et al., 2004; Laspiur et al., 2009) although it was higher than shown in another recent trial with hyper-prolific sows where the true milk protein content was approximately 4.5\% throughout lactation (Pedersen et al., 2016). The higher protein intake resulted in concomitant higher plasma concentrations of GGT, which supported the view that increased milk protein concentration was caused by increasing the uptake of amino acids, because this enzyme has been shown to be involved in the mammary gland uptake of amino acids in rats (Viña et al., 1981a and 1981b) The piglet has a high rate of muscle growth and therefore a high protein requirement (Theil and Jørgensen, 2016), and the litter gain reached maximum at $135 \mathrm{~g} \mathrm{SID} \mathrm{CP/kg}$, which is identical to the dietary SID CP concentration which resulted in maximum milk protein content (136 g SID CP/kg).

\section{Changes in body composition}

Lactating sows often turn catabolic, and therefore milk nutrients are derived from both diet and body reserves. The decrease in BW loss in the current experiment was mainly a result of 
Strathe, Bruun, Tauson, Theil and Hansen

Table 4 Body composition and changes in body composition in the sows measured by deuterium dilution technique ${ }^{1}$

\begin{tabular}{|c|c|c|c|c|c|c|c|c|}
\hline & \multicolumn{6}{|c|}{ SID CP $(\mathrm{g} / \mathrm{kg})$} & \multirow[b]{2}{*}{ SE } & \multirow{2}{*}{$\begin{array}{c}P \text {-value } \\
\text { Diet }\end{array}$} \\
\hline & 104.3 & 113.3 & 120.9 & 128.5 & 139.2 & 150.0 & & \\
\hline \multicolumn{9}{|c|}{ Body composition day 3} \\
\hline Water $^{2}(\mathrm{~kg})$ & 120 & 125 & 123 & 120 & 126 & 127 & 13.1 & 0.46 \\
\hline Ash (kg) & 7.7 & 8.1 & 8.0 & 7.7 & 8.1 & 8.2 & 0.20 & 0.51 \\
\hline Fat (kg) & 56.9 & 62.9 & 59.5 & 61.3 & 64.2 & 61.2 & 3.51 & 0.59 \\
\hline Protein $(\mathrm{kg})$ & 38.9 & 41.0 & 40.0 & 39.4 & 41.3 & 41.3 & 0.97 & 0.50 \\
\hline Fat:protein $(\mathrm{kg} / \mathrm{kg})$ & 1.47 & 1.53 & 1.50 & 1.55 & 1.56 & 1.49 & 0.07 & 0.85 \\
\hline Water (\% of BW) & 52.3 & 49.9 & 51.4 & 50.0 & 50.8 & 50.9 & 1.39 & 0.37 \\
\hline Ash (\% of BW) & 3.3 & 3.2 & 3.3 & 3.2 & 3.2 & 3.2 & 0.11 & 0.80 \\
\hline Fat (\% of BW) & 22.1 & 25.1 & 23.1 & 24.2 & 24.1 & 24.0 & 1.23 & 0.40 \\
\hline Protein ( $\%$ of BW) & 16.7 & 16.2 & 16.6 & 16.3 & 16.5 & 16.6 & 0.39 & 0.21 \\
\hline \multicolumn{9}{|c|}{ Body composition day 24} \\
\hline Water ${ }^{2}(\mathrm{~kg})$ & 116 & 120 & 123 & 124 & 126 & 131 & 3.99 & 0.16 \\
\hline Ash $(\mathrm{kg})$ & 7.7 & 7.9 & 8.1 & 8.2 & 8.3 & 8.8 & 0.29 & 0.08 \\
\hline Fat $(\mathrm{kg})$ & 46.5 & 50.6 & 52.2 & 47.7 & 52.8 & 47.9 & 3.70 & 0.55 \\
\hline Protein $(\mathrm{kg})$ & 37.1 & 38.4 & 39.3 & 39.1 & 40.4 & 41.1 & 1.28 & 0.24 \\
\hline Fat:protein $(\mathrm{kg} / \mathrm{kg})$ & 1.25 & 1.31 & 1.33 & 1.21 & 1.30 & 1.15 & 0.08 & 0.20 \\
\hline Water $(\%$ of BW) & 53.1 & 52.04 & 52.21 & 53.5 & 52.3 & 54.6 & 0.96 & 0.10 \\
\hline Ash (\% of BW) & 3.5 & 3.4 & 3.4 & 3.6 & 3.5 & 3.7 & 0.09 & 0.10 \\
\hline Fat (\% of BW) & 20.9 & 21.3 & 22.2 & 20.0 & 21.5 & 19.5 & 1.17 & 0.26 \\
\hline Protein (\% of BW & 16.8 & 16.5 & 16.7 & 16.8 & 16.7 & 17.1 & 0.19 & 0.13 \\
\hline \multicolumn{9}{|c|}{ Change in body composition ( $\%$ of mass at day 3 )2 } \\
\hline Water loss3 & 2.9 & 4.2 & 0.3 & -3.2 & 0.1 & -3.5 & 2.00 & $<0.01$ \\
\hline Fat loss & 19.4 & 20.3 & 16.1 & 23.8 & 20.9 & 22.9 & 4.50 & 0.41 \\
\hline Protein loss & 5.8 & 6.3 & 1.8 & 1.0 & 2.9 & 0.7 & 1.92 & 0.06 \\
\hline Ash loss ${ }^{3}$ & 0.8 & 2.2 & -1.5 & -6.8 & -2.8 & -7.3 & 2.43 & $<0.01$ \\
\hline
\end{tabular}

SID=standardized ileal digestible.

${ }^{1}$ The interaction of Diet $\times$ Parity was not significant $(P>0.05)$. For body composition on days 3 and 24 , there was an effect of Parity $(P<0.05)$, because of different BW of parity 2 and 3 sows. There was no effect of Parity on changes in body composition ( $P>0.05)$.

2 Body water was determined by the technique described by Theil et al. (2002).

${ }^{3}$ Negative values indicate a gain.

decreased body protein mobilization, because BF mobilization continued to increase with increased protein intake. A similar response to increased dietary protein was reported by Dourmad et al. (1998). This suggests that sows fed high levels of dietary SID CP use the dietary protein as substrate for milk protein and thereby save body protein. The lower protein mobilization in sows fed high SID CP levels were followed by decreased plasma ALT concentrations as a result of the downregulation of urea cycle enzymes (Das and Waterlow, 1974). Feeding protein-deficient diets results in a reduction of the body protein turnover to ensure a higher utilization of dietary protein. A lower plasma albumin concentration observed in sows fed low SID CP concentrations has also been shown in pigs suffering protein deficiency (Wykes et al., 1996), and this indicated that these sows had a reduced albumin synthesis. In this study, minimum body protein loss (128 SID CP g/kg) occurred at a dietary SID CP concentration close to that where milk protein was maximized (136 g SID CP/kg). In addition, the N balance was optimized at SID CP levels close to these concentrations as indicated by an increase in PUN in both early $(139 \mathrm{~g} \mathrm{SID} \mathrm{CP/kg)} \mathrm{and} \mathrm{late}$ (133 g SID CP/kg) lactation above these concentrations. The increase in PUN concentrations after the breakpoint indicated that protein intake above this dietary protein concentration was in excess of the requirement (Coma et al., 1995 and
1996). The breakpoint for PUN was reached at higher SID CP concentrations in early compared to late lactation, because of the lower daily CP intake in early lactation. Minimizing body protein mobilization during lactation is important, because it can be difficult for the sow to regain the lost body protein during the following gestation. This is in accordance with Dourmad et al. (1996), who reported that sows losing 35 v. $12 \mathrm{~kg}$ during lactation were unable to restore the body reserves, especially body protein, during subsequent gestation.

Body ash is a measure of bone mass, and therefore the lower mobilization of ash with a higher dietary protein intake suggests that bone mobilization was reduced. Low protein intakes reduce intestinal absorption of calcium and increase the concentration of parathyroid hormone, resulting in calcium being released from the bones (Heaney and Layman, 2008). This can negatively affect the longevity of the sows, because leg disorders are a cause of culling in sow herds (Engblom et al., 2007).

In the current study, milk fat content and BF mobilization increased with increasing dietary protein intake, which was in accordance with the results by King et al. (1993). This indicated that the mobilized body fat was redirected towards the mammary glands for milk fat production. Back fat loss increased with increased dietary protein, but changes in body fat estimated by $D_{2} O$ dilution technique was unaffected 
by the tested dietary protein levels, which is in accordance with Mejia-Guadarrama et al. (2002). The lacking response of body fat might be ascribed to the used equations (Rozeboom et al., 1994), which were developed on data from gilts. The increased BF mobilization suggests that the sows fed high levels of dietary SID CP most likely were in an energy deficit. Increased energy demand will often result in increased body fat mobilization, when energy intake is not increased at the same rate as the requirement. The six diets were isoenergetic, and this resulted in diets with different ratios between energy and protein. It has been observed in other studies that sows fed high CP levels increase BF mobilization (Tritton et al., 1996; McNamara and Pettigrew, 2002; Heo et al., 2008). However, it was also shown that both increasing dietary $\mathrm{CP}$ and energy level could minimize BF loss (Tritton et al., 1996; McNamara and Pettigrew, 2002), which emphasizes the importance of also determining the energy requirement of sows when increasing protein intake.

\section{Conclusions}

The SID CP requirement of hyper-prolific lactating sows was estimated at $135 \mathrm{~g} / \mathrm{kg}$ based on the ADG of the litter. At this level of SID CP, BW loss, body protein loss and body ash loss were considerably reduced, and $\mathrm{N}$ balance of the sows measured by PUN was optimized. The higher litter gain was a result of increased milk yield and higher contents of protein and fat in milk at peak lactation.

\section{Acknowledgements}

The project received financial support from the Pig Levy Foundation and from the EU and Rural Development Program under the Danish Ministry of Food, Agriculture and Fisheries, journal number 32101-U-13-00239, and the Faculty of Health and Medical Sciences, University of Copenhagen. Feed analysis was sponsored by Evonik Nutrition \& Care GmbH Tyskland Filial Denmark. Results in this article were presented in the PhD thesis of the first author (Strathe, 2017).

\section{Declaration of interest}

None.

\section{Ethics statement}

The Danish Animal Experimentation Inspectorate (Authorization No. 2013-15-2934-00961) approved the trial.

\section{Software and data repository resources}

None of the data were deposited in an official repository.

\section{References}

Bender DA 2012. The metabolism of 'surplus' amino acids. British Journal of Nutrition 108, S113-S121.
Coma J, Carrion D and Zimmerman DR 1995. Use of plasma urea nitrogen as a rapid response criterion to determine the lysine requirement of pigs. Journal of Animal Science 73, 472-481.

Coma J, Zimmerman DR and Carrion D 1996. Lysine requirement of the lactating sow determined by using plasma urea nitrogen as a rapid response criterion. Journal of Animal Science 74, 1056-1062.

Das TK and Waterlow JC 1974. The rate of adaptation of urea cycle enzymes, aminotransferases and glutamic dehydrogenase to changes in dietary protein intake. British Journal of Nutrition 32, 353-373.

Dourmad JY, Etienne M and Noblet J 1996. Reconstitution of body reserves in multiparous sows during pregnancy: effect of energy intake during pregnancy and mobilization during the previous lactation. Journal of Animal Science 74, 2211-2219. Dourmad JY, Noblet J and Etienne M 1998. Effect of protein and lysine supply on performance, nitrogen balance, and body composition changes of sows during lactation. Journal of Animal Science 76, 542-550.

Engblom L, Lundeheim N, Dalin A-M and Andersson K 2007. Sow removal in Swedish commercial herds. Livestock Science 106, 76-86.

EvaPig 2008. Evaluation of pigs feed. Reference manual. Retrived on 3 January 2017 from http://www.evapig.com/

Guan X, Pettigrew JE, Ku PK, Ames NK, Bequette BJ and Trottier NL 2004. Dietary protein concentration affects plasma arteriovenous difference of amino acids across the porcine mammary gland. Journal of Animal Science 82, 2953-2963. Hansen AV, Strathe AB, Kebreab E, France J and Theil PK 2012. Predicting milk yield and composition in lactating sows: a Bayesian approach. Journal of Animal Science 90, 2285-2298.

Hansen AV, Strathe AB, Theil PK and Kebreab E 2014. Energy and nutrient deposition and excretion in the reproducing sow: model development and evaluation. Journal of Animal Science 92, 2458-2472.

Heaney RP and Layman DK 2008. Amount and type of protein influences bone health. The American Journal of Clinical Nutrition 87, 1567S-1570S.

Heo S, Yang YX, Jin Z, Park MS, Ynag BK and Chae BJ 2008. Effects of dietary energy and lysine during late gestation and lactation on blood metabolites, hormones, milk composition and reproductive performance in primiparous sows. Canadian Journal of Animal Science 88, 247-255.

Huber L, de Lange CFM, Krogh U, Chamberlin D and Trottier NL 2015. Impact of deeding reduced crude protein diets to lactating sows on nitrogen utilization. Journal of Animal Science 93, 5254-5264.

Hurley WL 2015. Composition of sow colostrum and milk. In The gestating and lactating sow (ed. C Farmer), pp. 193-218. Wageningen Academic Publishers, Wageningen, The Netherlands.

King RH, Toner MS, Dove H, Atwood CS and Brown WG 1993. The response of first-litter sows to dietary protein level during lactation. Journal of Animal Science 71, 2457-2463.

Laspiur JP, Burton JL, Weber PSD, Moore J, Kirkwood RN and Trottier NL 2009. Dietary protein intake and stage of lactation differentially modulate amino acid transporter mRNA abundance in porcine mammary tissue. The Journal of Nutrition 139, 1677-1684.

Mejia-Guadarrama CA, Pasquier A, Dourmad JY, Prunier A and Quesnel H 2002. Protein (lysine) restriction in primiparous lactating sows: effects on metabolic state, somatotropic axis, and reproductive performance after weaning. Journal of Animal Science 80, 3286-3300.

McNamara JP and Pettigrew JE 2002. Protein and fat utilization in lactating sows: I. Effects on milk and body composition. Journal of Animal Science 80, 2442-2451.

National Research Council (NRC) 2012. Nutrient requirements of swine, 11th revised edition. National Academies Press, Washington, DC, USA.

Pedersen C and Boisen S 2002. Establishment of tabulated values for standardized ileal digestibility of crude protein and essential amino acids in common feedstuffs for pigs. Acta Agriculturae Scandinavica, Section A - Animal Science 53, 121-140.

Pedersen TF, Bruun TS, Feyera T, Larsen UK and Theil PK 2016. A two-diet feeding regime for lactating sows reduced nutrient deficiency in early lactation and improved milk yield. Livestock Science 191, 165-173.

Robbins KR, Saxton AM and Southern LL 2006. Estimation of nutrient requirements using broken-line regression analysis. Journal of Animal Science 84, 155-165.

Rozeboom DW, Pettigrew JE, Moser RL, Cornelius SG and el Kandelgy SM 1994. In vivo estimation of body composition of mature gilts using live weight, backfat thickness, and deuterium oxide. Journal of Animal Science 72, 355-366. 
Strathe AV 2017. Milk production, body mobilization and plasma metabolites in hyper-prolific sows - Effect of dietary valine and protein. PhD thesis, University of Copenhagen, Copenhagen, Denmark.

Strathe AV, Bruun TS, Geertsen N, Zerrahn J-E and Hansen CF 2017a. Increased dietary protein levels during lactation improved sow and litter performance. Animal Feed Science and Technology 232, 169-181. DOI: 10.1016/j. anifeedsci.2017.08.015

Strathe AV, Bruun TS and Hansen CF 2017b. Sows with high milk production had both a high feed intake and a high body mobilization. Animal 11, 1913-1921. DOI: $10.1017 /$ S1751731117000155.

Strathe AV, Strathe AB, Theil PK, Hansen CF and Kebreab E 2015. Determination of protein and amino acid requirements of lactating sows using a populationbased factorial approach. Animal 9, 1319-1328.

Theil PK and Jørgensen H 2016. Fat, energy, and nitrogen retention of artificially reared piglets. Journal of Animal Science 94, 320-323.

Theil PK, Nielsen TT, Kristensen NB, Labouriau R, Danielsen V, Lauridsen C and Jakobsen $\mathrm{K}$ 2002. Estimation of milk production in lactating sows by determination of deuterated water turnover in three piglets per litter. Acta Agriculturae Scandinavica, Section A - Animal Science 52, 221-232.

Tritton SM, King RH, Campbell RG, Edwards AC and Hughes PE 1996. The effects of dietary protein and energy levels of diets offered during lactation on the lactational and subsequent reproductive performance of first-litter sows. Animal Science 62, 573-579.

Trottier NL, Johnston LJ and de Lange CFM 2015. Applied amino acids and energy feeding of sows. In The gestating and lactating sow (ed. C Farmer), pp. 117-140. Wageningen Academic Publishers, Wageningen, The Netherlands. Tybirk P, Sloth NM and Jørgensen L 2014. Nutrient requirement standards, 19th edition. Danish Pig Research Centre, Copenhagen, Denmark.

Viña J, Puertes IR, Estrela JM, Viña JR and Galbis JL 1981a. Involvement of $\gamma$-glutamyltransferase in amino-acid uptake by the lactating mammary gland of the rat. Biochemical Journal 194, 99-102.

Viña JR, Puertes IR and Viña J 1981b. Effect of premature weaning on amino acid uptake by the mammary gland of lactating rats. Biochemical Journal 200, 705-708.

Wykes LJ, Fiorotto ML, Burrin DG, Del Rosario M, Frazer ME, Pond WG and Jahoor $F$ 1996. Chronic low protein intake reduces tissue protein synthesis in a pig model of protein malnutrition. Journal of Nutrition 126 1481-1488.

Yang H, Pettigrew JE, Johnston LJ, Shurson GC, Wheaton JE, White ME, Koketsu Y, Sower AF and Rathmacher JA 2000. Effects of dietary lysine intake during lactation on blood metabolites, hormones, and reproductive performance in primiparous sows. Journal of Animal Science 78, 1001-1009. 